\title{
An investigation on the relationship between quarterly earnings adjustment and market value in selected firms listed on TSE Exchange
}

\author{
Reza Tehrani ${ }^{a}$, Seyed Yousef Ahadi Serkani ${ }^{b}$ and Sodabe shokri ${ }^{c^{*}}$
}

${ }^{a}$ Prof. \& Faculty Member, Department of Finance, Tehran University, Iran

${ }^{b}$ Assist.Prof. \& Faculty Member, Department of Accounting, Firoozkooh Branch, Islamic Azad University (IAU), Iran

${ }^{c}$ M.Sc. Student, Department of Accounting, School of Management, Tehran North Branch, Islamic Azad University (IAU), Tehran, Iran

C H R O N I C L E

Article history:

Received October 28, 2012

Received in revised format

26 January 2013

Accepted 28 January 2013

Available online

February 42013

Keywords:

Tehran Stock Exchange

Quarterly adjustment

Market return

\section{A B S T R A C T}

\begin{abstract}
Earning reports are the primary basis of investment decisions among many individuals and fund managers. Any positive/negative adjustment on quarterly financial report could influence investment strategies, which consequently make significant change on market value. In this paper, we present an empirical study on some selected firms on Tehran Stock exchange by looking the effects of quarterly earning adjustment on firm and market's return. The proposed study selects all firms whose shares were actively and publicly traded over the period 20062011. The study investigates whether there is a meaningful relationship between the content of quarterly earnings report and stock price with/without the presence of control variables. The results have concluded that there are some meaningful relationships between change in earning and market value and return on firm with market value but market value seems to have no relationship with market return changes.
\end{abstract}

(C) 2013 Growing Science Ltd. All rights reserved.

\section{Introduction}

Earning reports are the primary basis of investment decisions among many individuals and fund managers. Any positive/negative adjustment on quarterly financial report could influence investment strategies, which consequently make significant change on market value (Cheng et al. 1997; Oppong, 1980). During the past few years, there have been different studies associated with the effects of earning adjustment on other financial figures. Ahmed et al. (2010) provided some evidence on the effects of online trading on stock price and trading volume reactions to quarterly earnings announcements. They examined for differences in stock price and volume reactions to quarterly earnings announcements between a period some data for the period 1996-99 with online trading and a period without online trading (1992-95) and their findings were relevant for assessing the validity of concerns about online trading expressed by regulators.

Corresponding author. Tel: +98-912-3443139

E-mail: m_khodaei@iau-tnb.ac.ir (S. Shokri)

(C) 2013 Growing Science Ltd. All rights reserved. doi: $10.5267 /$ j.msl.2013.02.005 
Ahmed and Schneible (2007) investigated the effect of regulation fair disclosure on investors' prior information quality - evidence from an analysis of changes in trading volume and stock price reactions to earnings announcements. Pownall et al. (1993) studied the stock price impacts of alternative types of management earnings forecasts. RO (1988) investigated firm size and the information content of annual earnings announcements. Cheung and Sami (2000) investigated price and trading volume reaction: the case of Hong Kong companies' earnings announcements.

According to Chen et al. (2005), The China Securities Regulatory Commission asks all listed companies to make earnings announcements by the end of April each year. This requirement has created a unique opportunity to evaluate the timing of earnings announcements in a four-month cluster. Firms, which are willing to make early announcements will more likely surprise the market, as indicated by the higher volume and price reactions. Their results indicated that an information asymmetry existed between early and late earnings announcements in Mainland China.

Chan et al. (2005) investigated the relationship between firm size and the information content of annual earnings announcements. They studied the impact of firm size on the market's short-window response to annual earnings announcements for a large sample of Australian listed firms. They used regressions of unexpected earnings against unexpected returns. They reported that firm size had either no impact on the response to earnings announcements (3 day window) or the response was substantially stronger for larger firms (twenty-one day window).

Vieru et al. (2006) concentrated on non-institutional trading behavior around interim earnings announcements in the emerging market. They separated the stock trading activity of Finnish households into five trading classes and compared the results to institutional trading. They reported that earnings news triggers trading in every trading class and found some evidence that actively trading individuals especially showed increased buying and selling activity before the event compared to the non-event period. In addition, they stated that the institutional trading class was clearly less influenced by the announcement than the active investor classes did.

The organization of this paper first presents the proposed method in section 2 while section 3 describes the results of our investigation. Finally, concluding remarks are given in the last to summarize the contribution of the paper.

\section{The proposed study}

In this paper, we present an empirical study on some selected firms on Tehran Stock exchange by looking the effects of quarterly earning adjustment on firm and market's return. The proposed study selects all firms whose shares were actively and publicly traded over the period 2006-2011.

The proposed study of this paper selects all firms whose shares were actively and publicly traded over the period 2006-2011. We also needed to have the access to historical stock price 20 days before and after the quarterly earning announcements. We have concentrated only on firms whose actual and predicted profits were different leaving us to have 41 firms with 820 historical data. In case, there were any interruption within the mentioned 41 days, the interruption should not have happened 10 consecutive or 15 non-consecutive days. There must be no increase in change in capital and the information of dividends must be available.

\subsection{The proposed hypotheses}

The proposed study considers the following two hypotheses,

1. There is a meaningful relationship between the content of quarterly earnings report and stock price. 
2. There is a meaningful relationship between the content of quarterly earnings report and stock price in the presence of control variables.

The proposed study uses Eq. (1) to validate the first model,

$$
\Delta M V_{i t}=\alpha+\beta_{1} \Delta e_{i t}+\varepsilon
$$

In addition, we use Eq. (2) to examine the second hypothesis as follows,

$$
\Delta M V_{i t}=\alpha+\beta_{1} \Delta e_{i t}+\beta_{2} \Delta R_{i t}+\beta_{3} \Delta R_{m t}+\varepsilon
$$

In Eq. (1) and Eq. (2), $\Delta M V_{i t}$ represents market value, $\Delta e_{i t}$ is the change in earning announcement and $\Delta R_{i t}$ is the change on return of firm $i$ on period $t, 20$ days before and after earning announcement and finally $\Delta R_{m t}$ is the change on return of market on period $t, 20$ days before and after earning announcement, respectively. In addition, $\alpha, \beta_{1}, \beta_{2}$ and $\beta_{3}$ represent the coefficients of the morel estimated by regression analysis and $\varepsilon$ is the residual. Table 1 demonstrates some of the basic statistics associated with four independent variables,

\section{Table 1}

Some basic information on the input data

\begin{tabular}{lccccc}
\hline Financial ratios & Mean & Median & Standard deviation & Skewness & Kurtosis \\
\hline Market value & 11410208163 & 854700000 & 144599975794 & 0.90 & 1.08 \\
Earning adjustment & -72776.79 & -23740.00 & 150219.15 & -3.71 & 17.39 \\
$\begin{array}{l}\text { Change in return of firm } \\
\begin{array}{l}\text { Change in return of } \\
\text { market }\end{array}\end{array}$ & 4.90 & 2.67 & 14.75 & 0.78 & 3.53 \\
\hline
\end{tabular}

The results of Table 1 shows that the distribution of variables are close to normal. We also consider Kolmogorev-smirnov test to have better understanding on the distribution of the data and the results are given in Table 2 .

\section{Table 2}

The results of Kolmogorev-smirnov test

\begin{tabular}{ccccccccc}
\hline & & & & \multicolumn{3}{c}{ Maximum changes } & \multicolumn{2}{c}{ Kolmogorev-smirnov } \\
\cline { 5 - 8 } Year & No. & Mean & Standard deviation & Absolute & positive & negative & Z & P-value \\
\hline 2006 & 123 & 28497389072 & 126544680680 & 0.28 & 0.28 & -0.11 & 1.21 & 0.11 \\
2007 & 163 & -5617463540 & 108225085658 & 0.14 & 0.13 & -0.14 & 0.93 & 0.35 \\
2008 & 164 & -1467420415 & 175674505294 & 0.23 & 0.23 & -0.14 & 1.19 & 0.12 \\
2009 & 164 & 12233252876 & 137899295338 & 0.19 & 0.19 & -0.14 & 1.19 & 0.12 \\
2010 & 123 & 42698255117 & 166664300381 & 0.18 & 0.18 & -0.16 & 0.77 & 0.60 \\
2011 & 41 & -49089809175 & 65909269930 & 0.14 & 0.09 & -0.14 & 0.88 & 0.42 \\
\hline
\end{tabular}

The results of $\mathrm{Z}$ and $\mathrm{P}$-value for Kolmogorev-smirnov test are all greater than 0.05, which mean the variables are normally distributed.

One of the important issues associated with any regression analysis is to make sure there is no strong correlations between any pairs of independent variables. We examine the following hypothesis between each pair of independent data, 
$\begin{cases}H_{0}: & \rho_{X Y}=0 \\ H_{1}: & \rho_{X Y} \neq 0\end{cases}$

Table 3

The results of Pearson correlation test

\begin{tabular}{lccc}
\hline Variable & $\begin{array}{c}\text { Quarterly earning } \\
\text { adjustment }\end{array}$ & $\begin{array}{c}\text { Difference in return of } \\
\text { firm }\end{array}$ & $\begin{array}{c}\text { Difference in return of } \\
\text { market }\end{array}$ \\
\hline Pearson correlation & -0.13 & 0.50 & 0.03 \\
P-value & 0.00 & 0.00 & 0.33 \\
Number & 819 & 819 & 819 \\
\hline
\end{tabular}

As we can observe from the results of Table 3, there is a negative correlation between seasonally earning adjustment and changes on value of market value of firms is equal to -0.13 with P-value of 0.000 . Therefore, the null hypothesis is rejected and we can conclude there is a negative correlation between these two variables.

In addition, Pearson correlation value between difference in returns of firms with market value of firms is equal to 0.50 with P-value of 0.00 , which means there is a relatively strong and positive correlation between these two components. Finally, Pearson correlation between market return change and market value of shares is equal to 0.03 which is not significant. In addition, spearman correlation ratio as non-parametric test is used between variables and Table 4 demonstrates the results of our survey.

Table 4

The results of Spearman correlation test

\begin{tabular}{lccc}
\hline Variable & $\begin{array}{c}\text { Quarterly earning } \\
\text { adjustment }\end{array}$ & $\begin{array}{c}\text { Difference in return of } \\
\text { firm }\end{array}$ & $\begin{array}{c}\text { Difference in return of } \\
\text { market }\end{array}$ \\
\hline Spearman correlation & -0.08 & 0.59 & 0.04 \\
P-value & 0.02 & 0.00 & 0.22 \\
Number & 819 & 819 & 819 \\
\hline
\end{tabular}

The results of Table 4 show that there is a negative correlation between seasonally earnings adjustment and changes on value of market value of firms is equal to -0.08 with P-value of 0.02 . Therefore, the null hypothesis is rejected and we can conclude there is a negative correlation between these two variables. In addition, Spearman correlation value between difference in returns of firms with market value of firms is equal to 0.59 with P-value of 0.00 , which means there is a relatively strong and positive correlation between these two components.

\subsection{Panel analysis}

Panel analysis is used to integrate different data with or without using fixed effects and Chaw and Husman tests can used to choose the appropriate model, i.e. choosing intercept or not, having random effect or not.

\subsubsection{The first model}

Implementation of Chaw test on Eq. (1) yields F-value $=1.927$ with p-value $=0.001$. Chi-Square is equal to 77.449 with 40 degree of freedom and $\mathrm{p}$-value $=0.000$. Therefore, the integration model cannot be used and model with fixed effect must be chosen. The results of Husman test yields ChiSquare $=0.006$ with $p$-value $=0.101$, which means the model with random effects is more suitable for our study. 


\subsubsection{The second model}

Implementation of Chaw test on Eq. (2) yields F-value $=2.328$ with p-value $=0.001$. Chi-Square is equal to 92.931 with 40 degree of freedom and $p$-value $=0.000$. Therefore, the integration model cannot be used and model with fixed effect must be chosen. The results of Husman test yields ChiSquare $=6.237$ with $\mathrm{p}$-value $=0.937$, which means the model with random effects is more suitable for our study.

\section{The results}

In this section, we present the results of our survey for the implementation of two models.

\subsection{The first model}

$$
\begin{aligned}
& \Delta M V_{i t}=3.26 \times 10^{9}-117957 \Delta e_{i t}+\varepsilon, \\
& \text { t-value } \quad 0.440 \quad-3.243 \quad \text { F-value }=10.524 \\
& \text { p-value } 0.660 \quad 0.001 \quad \mathrm{D}-\mathrm{W}=1.998
\end{aligned}
$$

The results of Eq. (3) show that there is a negative relationship between $\Delta e_{i t}$ and $\Delta M V_{i t}$. In addition, tstudent associated with this variable is meaningful. In addition, F-value is statistically significance and Durbin-Watson is also statistically meaningful, which means the relationship is linear and there is no auto-correlation among residuals. In other word, an increase of one unit in $\Delta e_{i t}$ will reduce $\Delta M V_{i t}$ by $-117957$.

\subsection{The second model}

$$
\begin{aligned}
& \Delta M V_{i t}=-2.15 \times 10^{10}-129850.5 \Delta e_{i t}+5.03 \times 10^{9} \Delta R_{i t}+1.06 \times 10^{10} \Delta R_{m t}+\varepsilon, \\
& \text { t-studnet }-3.152 \quad-4.105 \quad 16.954 \quad 0.793 \quad \text { F-value }=100.555 \\
& \mathrm{D}-\mathrm{W}=2.041
\end{aligned}
$$

The results of Eq. (4) demonstrate that there is a negative relationship between $\Delta e_{i t}$ and $\Delta M V_{i t}$. In addition, t-student associated with this variable is meaningful. In addition, F-value is statistically significance and Durbin-Watson is also statistically meaningful, which means the relationship is linear and there is no auto-correlation among residuals. In other word, an increase of one unit in $\Delta e_{i t}$ will reduce $\Delta M V_{i t}$ by -129850.5 . T-student value is also meaningful and positive relationship between $\Delta R_{i t}$ and $\Delta M V_{i t}$ but there is no meaningful relationship between $\Delta R_{m t}$ and $\Delta M V_{i t}$. The R-Square is equal to $27 \%$, which means the regression describes 27 percent of the changes we expected.

\section{Conclusion}

In this paper, we have presented an empirical investigation to find the effect of earnings adjustment on firms' return and market value. The proposed study used linear regression technique on data gathered from Tehran Stock Exchange. The results of this study have disclosed that there were some meaningful relationship between market value and quarterly earnings adjustment. 


\section{Acknowledgment}

The authors would like to thank the anonymous referees for their constructive comments on earlier version of this work.

\section{References}

Ahmed, A. S., \& Schneible, R. A. (2007). The impact of regulation fair disclosure on investors' prior information quality - evidence from an analysis of changes in trading volume and stock price reactions to earnings announcements. Journal of Corporate Finance, 13(2), 282-299.

Ahmed, A. S., Schneible, R. A., \& Stevens, D. E. (2010). An empirical analysis of the effects of online trading on stock price and trading volume reactions to earnings announcements. Contemporary Accounting Research, 20(3), 413-439.

Chan, H., Faff, R., \& Ramsay, A. (2005). Firm size and the information content of annual earnings announcements: Australian evidence. Journal of Business Finance \& Accounting, 32(1-2), 211 253.

Cheng, A., Chan, K. H., \& Liao, W. (1997). An investigation of market response to earnings announcements: Multinational firms versus domestic firms. The International Journal of Accounting, 32(2), 125-138.

Chen, G., Cheng, L. T., \& Gao, N. (2005). Information content and timing of earnings announcements. Journal of Business Finance \& Accounting, 32(1-2), 65-95.

Cheung, D. K., \& Sami, H. (2000). Price and trading volume reaction: the case of Hong Kong companies' earnings announcements. Journal of International Accounting, Auditing and Taxation, 9(1), 19-42.

Oppong, A. (1980). Information content of annual earnings announcements revisited. Journal of Accounting Research, 574-584.

Pownall, G., Wasley, C., \& Waymire, G. (1993). The stock price effects of alternative types of management earnings forecasts. Accounting Review, 896-912.

RO, B. T. (1988). Firm size and the information content of annual earnings announcements. Contemporary Accounting Research, 4(2), 438-449.

Vieru, M., Perttunen, J., \& Schadewitz, H. (2006). How investors trade around interim earnings announcements. Journal of Business Finance \& Accounting,33(1-2), 145-178. 